\title{
DEFINING CONDITIONS FOR INCREASING INNOVATION ACTIVITY IN THE INDUSTRIAL COMPLEX: ESSENCE, SYSTEMATIZATION, IDENTIFICATION
}

\author{
Tetiana Hushtan ${ }^{1}$, Anatoliy Kolodiychuk ${ }^{2}$
}

\begin{abstract}
The subject of the study is to substantiate classifications of the factors of innovation development of the industry: according to the priority, traditional, barrier, according to the hierarchical level of innovation, the nature of supply demand for innovation, the peculiarity of the influence of factors on the market environment, the influence of factors on innovation localization, importance of innovations, the effect of innovation, nature of the impact, the power of influence, the type of competition, and other classifications of factors of innovation development of the industry. The need to intensify the development of Ukrainian industry in an innovative way requires the identification of the impact on these processes of various factors. To group these influences, the assessment of these factors should be done in the context of separate classes. For this purpose, it is necessary to develop a classification of innovative factors of industrial development. The purpose of the paper is to investigate and systematize the defining conditions for the activation of innovative development in the industrial sphere. The following methods were used in the work: dialectical method of scientific knowledge, analysis and synthesis, comparative, as well as the method of data generalization. It is proved that the complex non-use of these classifications for the substantiation of innovative development of the industry will improve the quality of planning and forecasting documentation and provisions of industrial policy. The applied meaning arising from the criteria for the classification of factors is based on their specific spatiotemporal and situational application, in particular, in conditions of imperfect competition. The classification of innovative factors of industrial development according to their priority is given. In this classification, the priority is determined by the importance and relevance of innovative industry development tasks on the basis of conclusions made as a result of the literature review. Summarizing the factors of innovation development in the barrier classification allows us to distinguish three aggregated groups of factors: socio-political and managerial, socio-economic, and financial. Our socio-economic analysis of innovative development factors of industry also allowed us to identify the following their classification attributes: the hierarchical level of innovation implementation, the character of demand for innovation, the nature of the impact on the market environment, the type of impact, the time horizon of action, impact on the area of innovation localization, the economic essence of innovation, the nature of the significance of innovation, innovation effect, the nature of effective impact, the power of influence, the type of competition.
\end{abstract}

Key words: innovation development, industry, conditions, systematization, classes, processes, priority, competition.

JEL Classification: E23, O31

\section{Introduction}

Innovative development of the industry is influenced by a number of factors. These factors can be structured both vertically and horizontally. The structuring of factors "vertically" is essentially a reflection of the hierarchical groups of factors and the peculiarities of their influence. If we talk about the classification of factors "horizontally," we mean how different factors of the same hierarchical level affect the development of the industry. In this case, imperfect competition can be regarded as a special group of factors.

\footnotetext{
Corresponding author:

${ }^{1}$ Uzhhorod Institute of Trade and Economics of Kyiv National University of Trade and Economics, Ukraine.

E-mail: hushtantetiana@gmail.com

ORCID: https://orcid.org/0000-0002-0299-0437

ResearcherID: https://publons.com/researcher/4506839/

${ }^{2}$ Uzhhorod Institute of Trade and Economics of Kyiv National University of Trade and Economics, Ukraine.

E-mail: kolodiychuka@i.ua

ORCID: https://orcid.org/0000-0001-5727-0560

ResearcherID: https://publons.com/researcher/3438947/anatoliy-kolodiychuk/
} 
Therefore, the need to intensify the development of Ukrainian industry in an innovative way requires identifying the impact on these processes of various factors. To group these influences together, these factors must be evaluated in the context of individual categories. To do this, it is necessary to develop a classification of factors of innovation development of industry.

At the present stage, the problem of radical improvement of the parameters of the structure and efficiency of domestic industrial production requires the intensification of innovative industrial development. Under the conditions of state deindustrialization, loss of its competitive position in the innovative sphere, on the one hand, and globalization of markets, technologies and capital on the other hand, innovative development and achievement of competitive business, socio-economic conditions remains one of the driving forces of industrial revival and economic growth.

Also, at the present stage, the conditions of innovation activity in Ukraine have become more complicated due to the deepening of imperfect competition, which manifests itself as an increase in the share of companies evading taxes in various ways, intensification of monopolization of certain markets, inhibition of innovation infrastructure and innovation range.

Innovative development of industry is influenced by a number of factors. These factors can be structured both "vertically" and "horizontally". Structuring factors "vertically" is essentially a reflection of hierarchical groups of factors and features of their influence. If we talk about the classification of factors "horizontally", we mean how various factors of one hierarchical level affect the development of industry. At the same time, imperfect competition can be considered as a special group of factors.

\section{Analysis of recent research and publications}

The problems of determining the factors of innovative development of industry at the macro and micro level, their classification, patterns of the stimulating and inhibiting factors, the issue of developing an effective state mechanism for activating innovation development in industry were studied by scientists V. Bozhkova (2011), O. Horodyskyi (2007), L. Solyanyk, Yu. Hrachova (2008), O. Ihnatenko (2008), S. Illyashenko (2010), O. Kuzmin, T. Kuzhda (2009), D. Panteleychuk (2009), and others. Factors of innovation development of industrial enterprises were studied by O. Kuzmin, T. Kudzhda (2009); spatial factors of innovation industrial development were considered in works of L. Shevchuk (2011), S. Schults (2010); environmental factors of innovation development of industry were investigated by
V. Bozhkova (2011), S. Illyashenko (2010). However, many problems related to the classification of factors of innovation development of industry remain unclear.

The aim of the article is to investigate and systematize the determining conditions for enhancing innovative development in the industrial sphere.

\section{Definitive conditions for enhancement of innovation activity in the industrial complex}

The determining place in the management of the industrial innovation development is the elucidation of industrial innovation development factors. First of all, let us note that under the category of "factor of innovation development of industry" we will understand the driving force of the system process, which is based on sound models and concepts, is based on the results of scientific and technological progress, which results in a strategic regulatory impact on industry, and which ends in a significant improvement in the structure and quality of industrial production.

Based on the study of several literature sources and the study of experience in the implementation of innovation, we developed a number of classifications of industrial innovation development in accordance with the classification criteria, which are shown in Figure 1.

It is known a number of factors of innovative development of industry, which differ in importance, duration, priority, etc. In the scientific literature, scientists use two approaches to the classification of factors: the traditional and by the priority of factors. We used both approaches.

First, let us consider the traditional classification of innovative industrial development factors. The traditional classification developed by us contains the following groups of innovative industrial development factors:

\subsection{Geographic (natural-, political-, economic-, and social-geographic) position}

This group of factors reflects the influence of geographical factors on the innovative development of industry. The natural and geographical position affects the innovative development of industry through the relief, climate, hydrosphere of the territory in which the industrial facilities are located. The essence of the political and geographical position is reduced to the localization of the existing political situation. The influence of political and geographical location on the innovative development of industry is determined by the placement of industrial facilities in relation to state borders, political blocs of countries, territories with political instability, national and international transport corridors, etc. The influence of economic and geographical location on innovation activity in industry is manifested through the location of industrial 


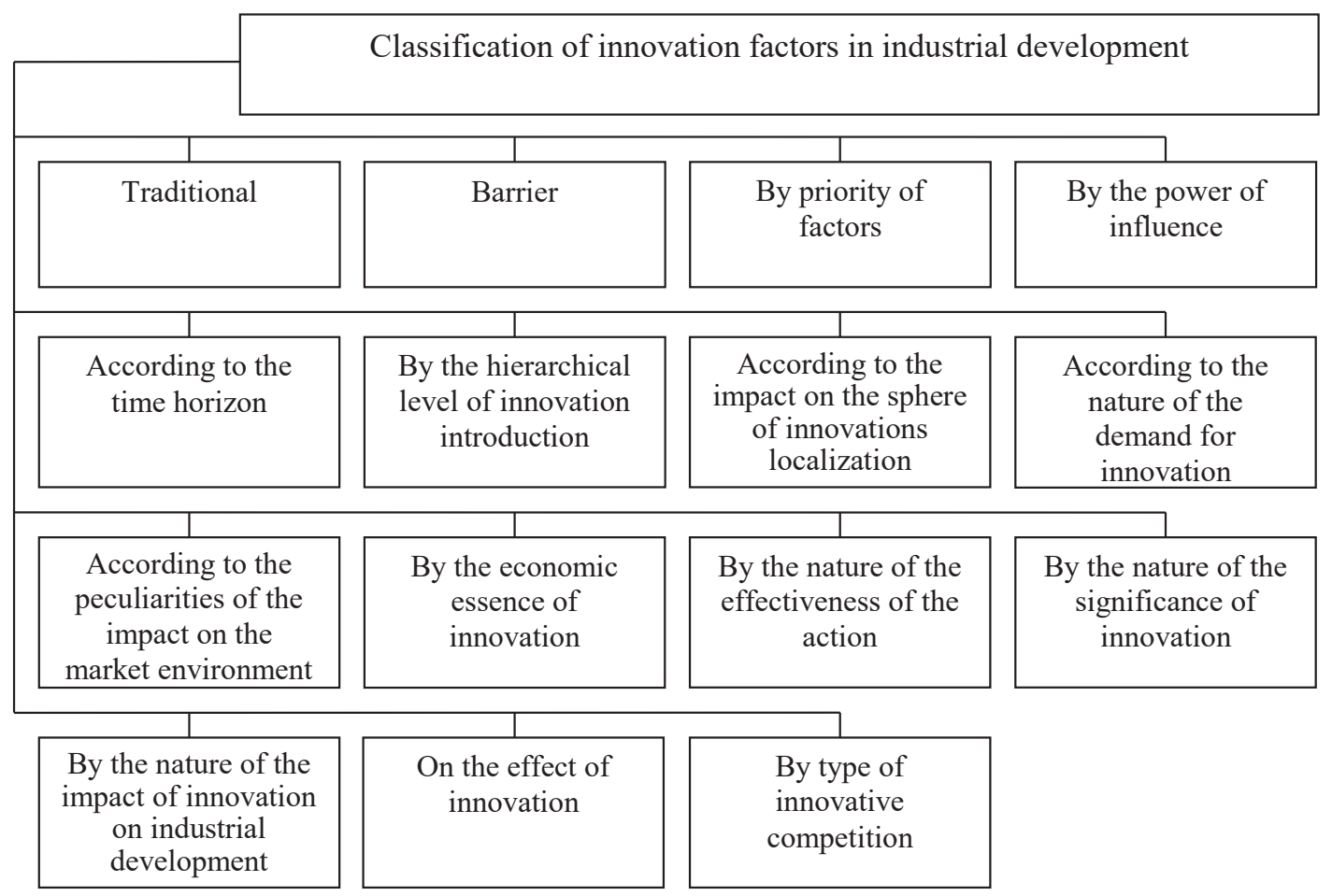

Figure 1. Classification of innovation factors in industrial development

Source: compiled by authors

facilities in relation to objects of economic value to them (markets for raw materials, markets for innovative products, customs borders, settlements, domestic and cross-border commodity and passenger flows, etc.). The socio-geographical position reflects the influence of territorial differentiation of the living standards of the population on the innovative development of industry. Natural resource potential is a set of natural resources and stocks that can be used to innovation development of industry and able to provide it.

We also made a classification of innovative industrial development factors by priority. As L.T. Shevchuk notes, "the essence of the classification of factors by priority the value of their action lies in the fact that primarily consider factors whose influence in a particular spatiotemporal coordinate systemisgreatest" (Shevchuk,2011).In ourclassification, the priority is determined by the importance and relevance of innovative industrial development tasks based on the conclusions made in the development of the literature. In this case, the first place is given to the factors of actual innovative development of the industry (factors of the first order), which directly affect the innovative activity. The factors of innovation industrial development are follows: technology; legislation in the field of innovation activity; demand for innovative products; competitors; monetary policy of the state in the field of innovation activity; fiscal policy of the state in the field of innovation development of industry; development of international economic activity; the significance of the proposed innovation; business development; level of economic risk; investment resources (own, borrowed, attracted); information resources (including the Unified Information Database of Scientific and Technological Research); the volume of cost of innovation; payback period of innovations; bank lending of innovation sphere; insurance of innovation activity; the volume of state financial support for innovation development; the level of development of inter-firm innovation cooperation; the presence of cluster structures; formation of joint innovative projects (state, interstate and interregional level); technology transfer; cooperation of research institutions; venture business.

\subsection{Behavioral, innovation-entrepreneurial, and environmental factors}

The second-order factors include behavioral, innovation-entrepreneurial, and environmental factors. Behavioral factors reflect the impact on the main generating force of innovative development, namely the highly skilled labor force. Behavioral factors are follows: motivation of staff; readiness of personnel for innovations; level of personnel training; wage level; system of incentives for innovative activity; level of social status of staff; the prestige of innovative activity in society (the state of innovation culture); public 
recognition of innovative developments; the level of involvement of employees in making managerial decisions in the field of innovation activity; the possibility of further career advancement; international scientific, interregional, national cooperation; the level of communication "science and production", the possibility of commercialization of innovative developments; "outflow of minds"; development of innovative culture.

Innovation-entrepreneurial factors influence on the innovative development of industry at the micro level, and the innovative development of industry represents a synergistic effect from the innovation activity of entrepreneurial structures. Innovative entrepreneurial factors are follows: efficiency of business management; specialization of the enterprise; organizational structure of the enterprise; personnel of the enterprise; suppliers of the enterprise; management technologies; consumers of innovative products of the enterprise; financial results of the enterprise activity; profitability of innovative products of the enterprise; regional government procurements of innovative products.

Environmental factors reflect the influence of spatial aspects of innovative development, the location of productive forces on the intensification of innovative activity; affect the development of the environment that makes possible the adoption of innovation. Environmental factors are follows: geographic location; natural and climatic conditions; demographic development; resources; infrastructure; availability of technology parks, logistics centers; development of the financial market; level of education in the country; available level of scientific and technological progress; investment attractiveness of national industry for both domestic and foreign investors; efficiency of the mechanism of state innovation policy; innovative exhibitions, fairs, contests.

Ecological factors take into account the impact of the environment on the industrial development, the impact of new technologies on the ecology. Ecological factors include: the impact of new technologies on the nature; the impact of new materials on the environment; the impact of new types of energy on the ecology; the impact of environmental regulations on the level of cost of innovative products; the impact of the environment on the quality of the workforce that introduces innovations; the benefits of implementing resource- and energy-saving technologies.

\subsection{Other factors of innovative industrial development}

The barrier classification developed by us contains the following groups of factors of innovation development of industry: legislative, political, managerial, economic, social, financial, environmental, scientific and technical, spatial, consumer, marketing, infrastructure, institutional, informational, humanitarian. A barrier may be any of the factors listed above, which makes it impossible to carry out innovation in the industry.

The combination of legislative factors creates a legal and regulatory framework for the innovative development of industry. These factors regulate innovation processes at industrial enterprises, ensure the implementation of industrial reform on the path of innovative development. The influence of political convictions of the population, political parties, political events in the country on the development of the industrial sphere in an innovative way reflects political factors. Managerial factors influence on the efficiency of innovative management of industry in general and management of innovation activities at industrial enterprises in order to increase their competitiveness. The general economic situation in the country reflects economic factors, including: development of entrepreneurship, international economic activity of the country, tax pressure. Ensuring the needs of industry in a highly skilled workforce to intensify innovative activity, creating favorable conditions for its productive creative work, as well as meeting the demand for innovative products reflect the social factors of innovative development of industry.

Financial support of innovative development of industry reflects financial factors. Financial factors, in turn, reflect the influence of monetary, fiscal and depreciation levers on the innovative development of industry in general, as well as industrial enterprises in particular.

The requirement of ecological safety of industrial production in the process of activating innovation processes puts by a group of environmental factors, which reflects the environmental impact on the innovation-intensive industry. The group of scientific and technical factors of innovation development of industry outlines the development of scientific and technological progress, the potential of scientific personnel, technological basis of innovation development of industry, etc.

First of all, the spatial factors embody the influence of the placement of innovative active industrial enterprises in relation to the sources of raw materials, labor markets, markets for sales of innovative products. According to L.T. Shevchuk, the factors of placement can be simultaneously factors of development (Shevchuk, 2011). E. Alayev in the paper (Alayev, 1983) notes that the same resource which, in relation to the object, served as a factor for the placement of the latter, correlated with the corresponding territory, can be considered as a development factor.

Influence of the level of prices and non-price characteristics of innovative products on the innovative development of industry has been reflected in 
consumer factors. The conditions of the distribution of innovative products and the provision of innovative services in the market determine the marketing factors of innovation development of industry. Impact of development of scientific and innovative infrastructure on the course of innovative processes in industry is reflected in the group of infrastructure factors of innovation development of industry. Influence of changes in institutions (the market of high-tech products, contractual relations in innovative business structures and between them, intellectual property relations) on the development of innovation activities in industry is taken into account in a group of institutional factors.

One of the key groups in terms of resource provision of ground-breaking development of industry is a group of information factors. The group of information factors creates an information base for activation of innovation movement in the industry, which contains data on innovative developments and investmentinnovative alternatives. Information resources are the source of innovation development. The factors of this group should include the following: providing industrial enterprises with access to scientific-technical, business and specialized information; assortment and cost of access to information products and services; access of educational institutions to foreign information resources; development of information infrastructure, etc.

The level of qualification and experience of managers and their accountable workforce in industry, necessary to enhance innovation, reveal the humanitarian factors of innovative development of industry.

The use of the barrier classification of innovative industrial development factors, which we have compiled, is of applied nature, and the strength of the impact of certain factors depends on the specific situation. In addition, in many cases it is necessary to take into account the multicollinearity of innovative industrial development factors (i.e. the strengthening of the influence of some factors at the expense of the action of others).

Summarizing the factors of innovation development in the barrier classification allows us to distinguish three aggregated groups of factors: socio-political and managerial, socio-economic, and financial. Methods of research that are adequate to relevant approaches are given in Table 1.

By the hierarchical level of innovation introduction, factors of innovation development of industry can be divided into:

- global. A group of global factors involves factors of global level that have an impact on the innovative development of industry through globalization processes in the world. Examples of such factors include the activity of the United Nations Industrial Development Organization (UNIDO), the policy of lending from the International Monetary Fund, the dynamics of indicators for the development of the world economy;

- international. The group of international factors includes factors influencing innovation processes in industry through the system of international economic relations covering two or more countries. It includes integration associations of countries, state and dynamics of global capital movement, state and dynamics of international technology movement, state and dynamics of transnational workforce movement;

- macroeconomic. Macroeconomic factors influence the innovative development of industry at the level of the national economy. Among these factors are the following: monetary policy of the central bank, fiscal policy in the state, development of strategies for innovative development of industry within the country, state standards of technical education, etc.;

- regional. At the regional level, such factors are important in the innovative development of industry. For example, the infrastructure of the region, the investment attractiveness of the region;

- microeconomic. At the level of individual business structures, the innovative development of the industry is influenced by microeconomic factors. Among them are the following: efficiency of business management; organizational structure of the entity; specialization of the entity; personnel of the enterprise; suppliers of the company; financial results of the enterprise; management technology at the company; consumers of innovative products of the company; profitability of innovative products of the company.

According to the nature of the demand for innovation. Factors of new demand are as follows: the deployment of scientific and technological progress;

Table 1

Research methods to be used in appropriate approaches to the classification of innovative industrial development factors

\begin{tabular}{|c|c|}
\hline Approach to the classification of innovative industrial development factors & Method of research \\
\hline Traditional & Descriptive and Analytical \\
\hline By the priority of the factors & Sociological Survey \\
\hline Barrier & Correlation and Regression Dependencies \\
\hline
\end{tabular}

Source: compiled by authors 
factors of existing demand: increasing income levels of the population.

The group of new demand factors includes the factors of innovative development of industry, which form the prerequisites for the emergence of new consumer needs. The group of existing demand factors includes the factors of industrial innovation development, which provide the growth of consumption of existing goods of innovative origin.

The factors of specific influence on the market environment include: diversification factors in innovation markets; the level of scientific and technological progress; factors of market environment development for the implementation of innovation; market infrastructure.

Diversification factors in innovation markets provide modification and expansion of innovations in existing markets. Market development factors for innovation expand markets for existing innovations.

Factors by the nature of the influence of innovations on industrial development include factors of direct influence: consumers, suppliers, legislative base, competitors; as well as factors of indirect influence: political events in the country, the development of innovation culture in society, the level of scientific and technological progress, the level of technology development.

Factors in the time horizon of action include: long-term (more than 5 years) - the strategy of innovation development of industry; medium-term (1-5 years) - cooperation of innovative active business structures; short-term (less than 1 year) - market conditions.Long-term factors ofinnovative development of industry are strategic, medium-term are operational, and short-term are tactical.

Factors of influence on the sphere of localization of innovations include: industrial (available fixed assets), technological (new production technologies), managerial (motivation of management personnel, management strategies in the conditions of intensification of innovative activity, management personnel), social (income level of the population).

Production factors ensure the approbation and use in industrial production of innovative design developments that are aimed both at the simple expansion of production, and to improve its structure and types of production activities. Technological factors create the necessary prerequisites for the introduction of industrial production innovative methods. Management factors provide innovative transformation of organizational management structures at industrial facilities (microlevel), industries (meso-level) and industry as a whole (macrolevel), the improvement of management methods and leadership styles. Social factors provide an opportunity to improve the standard of living of the population employed in industry.
Factors of economic essence of innovations include factors of influence on product innovations (level of scientific and technological progress), as well as factors of influence on procedural innovations (development of managerial technologies).

Factors influencing the formation and use in industry of food innovation (i.e., a new product or new service), which are characterized by market orientation, constitute the group of factors influencing product innovation. Factors affecting procedural innovations contribute to the improvement of various processes in industrial enterprises (production, management, etc.), which increases the efficiency of their activities.

Factors by the nature of the importance of innovations include: factors of basic innovations (level of scientific and technological progress, epochal discoveries and inventions), factors of ordinal innovations (chain effect of consumption), factors of extraordinary innovations (snobbery effect in consumption), and factors of point-selective innovations (regional characteristics of demand).

Factors of basic innovations affect the practical implementation of significant advances in science and technology, which significantly change the conditions of competitive processes, transferring them to a qualitatively new, more technologically advanced level. Factors of point-selective innovations affect the emergence and implementation of localized innovations with limited opportunities for their use. It is worth noting that a group of these factors, although increasing the efficiency of industry, but has a local nature.

Factors and their effect of innovation: factors providing economic effect (reducing the cost of innovative products), factors providing social effect (public access to information technology), factors providing environmental effect (new environmentally friendly technologies), factors providing comprehensive effect.

Factors that ensure the growth of profits from the introduction of innovation, becomes a group of factors that provide the economic effect. Factors for achieving social results from the implemented innovations form a group of factors that ensure the social effect. Factors reflecting environmental requirements for innovation are reflected in the group of factors providing the environmental effect. Factors providing profit, social results and environmental impact are reflected in the group of factors providing complex (integral) effect of innovations.

The slowdown of innovative development of domestic industry is a negative sign of the current period of development of the national economy. This problem is caused by a number of factors of negative influence on the activation of innovative activity in industry, from insufficient funding to the lack of highly skilled workforce 
in industrial enterprises, which could generate innovative developments.

Factors by the nature of the impact of innovation on industrial development can be divided into positive (stimulating) and negative (inhibiting). Thus, the group of stimulating factors can be attributed to the factors that distinguished scientist T. I. Horodyskyy (resource-legislative and management approach). In particular, he notes the following factors (Horodyskyy, 2007): regulatory, finance and economics (system of financing innovative activity, system of formation of favorable economic environment in the innovation sphere) and organizational (mechanism of innovation activity realization, formation and implementation of innovation policy).

We can distinguish the following approaches to the classification of inhibitory factors: macroeconomic, resource and potential, legislative, resource and management. Thus, the macroeconomic approach (that is, the approach from the standpoint of state economic policy in the direction of ensuring the innovation development of domestic industry) is presented in the works of N. S. Somenkova, which distinguishes the following factors that hinder or restrict innovation activity: high cost of innovation, low level of scientific and technological potential, low level of interaction and cooperation in the development of technological innovations, insufficient financial support of the state, lack of own funds, shortage of skilled personnel (Somenkova, 2008). Resource and potential approach has been reflected in the studies of D. Yu. Panteleychuk, who highlights such inhibitory factors: low investment activity of domestic and foreign investors, low level of state financing of innovation development and lack of own funds of enterprises, weakening of relations of science and production, imperfection of tax legislation (Panteleychuk, 2009). However, in our opinion, the most complete group of inhibitory factors was described by O. Ya. Ihnatenko (Ihnatenko, 2008) (resourcelegislative and management approach), distinguishing in this group three subgroups: economic (insufficient financial support of the state, lack of own funds, high costs on the innovation, long payback period of innovations, underdevelopment of the financial market and unwillingness of capital to a large investment in the innovation sphere, the complexity of attracting external financial resources due to the low attractiveness of the Ukrainian industry for investment; the uncertainty of the terms of the innovation process, the high economic risk, low level of solvent demand for products), production (lack of information on sales markets, lack of information on new technologies, enterprises' unresponsiveness to innovations, lack of opportunities for cooperation with other enterprises and scientific organizations, lack of qualified management of innovative processes aimed at obtaining competitive advantages ) and legal (imperfection of instruments of legal regulation of innovation activity, lack of optimal level of taxation).

Under the influence of factors of innovation development of industry can be divided into: factors of weak influence (geographical location, natural and climatic conditions), factors of medium impact (insurance of innovation activity, amount of state financial support for innovation development, presence of cluster structures, international scientific, interregional and national cooperation, "brain drain", specialization of enterprise, organizational structure of enterprise, enterprise suppliers, environmental impact on quality of labor that introducing innovations), factors of strong influence (competitors, monetary policy of the state in the field of innovation activity, level of economic risk (Kolodiychuk, 2017), information resources, bank lending, personnel motivation, level of social status of personnel, public recognition of innovation developments, level of communication "science and production", possibility of commercialization of innovative developments, personnel of the enterprise, management technologies, financial results of the enterprise activity, profitability of innovative products of the enterprise, investment attractiveness of national industry for domestic and foreign investors, the effectiveness of the mechanism of state innovation policy, the impact of new technologies on the environment, the impact of environmental regulations on the level of innovative products cost), very influential factors (technology, legislation in the field of innovation, demand for innovative products, fiscal policy of the state in the field of innovation development of industry, entrepreneurship development, investment resources, amount of expenses for innovation, level of personnel training, level of wages, incentive system for innovation activity, resources, infrastructure, availability of technology parks, logistic centers, level of education in the country, available level of scientific and technological progress).

According to the influence on the conditions of imperfect competition factors of innovative development of industry can be divided into the following: factors of innovation development of industry, which exacerbate the conditions of imperfect competition (patent and licensing legislation), factors of innovative development of the industry that do not affect the conditions of imperfect competition (the level of scientific and technological progress), factors of innovation development of industry that mitigate the conditions of imperfect competition (state antimonopoly regulation in the markets of scienceintensive and innovative products).

Factors by types of innovative competition include the following: factors of innovative development of perfect competition industry (state antimonopoly regulation, transparency of government agencies, lack 
of barriers to entry-exit to the market, free access to market information, availability of substitute goods, etc.), factors of innovative development of imperfect competition industry (monopolization, corruption, insiderism, etc).

It is important to note that the most important factor in the innovation development of imperfect competition is monopolization. The monopolized position does not stimulate the monopolistic enterprise to innovative activity, as it provides not a competitive advantage in the form of implementation of innovative developments, but the elimination of competitors. Nevertheless, modern monopolies face "challenges" from related industries, which they eliminate with the help of innovative technologies, the use of which allows to reduce the cost of production. However, despite the high concentration of capital, the priority for the monopolist is to maintain a privileged position in the market, not the cost of leadership in innovative development. Under conditions of thriving imperfect competition, administrative monopoly, which is created by granting exclusive rights to certain enterprises to engage in certain types of economic activity, has a particularly negative impact on innovative activity.

\section{Conclusions}

Thus, in the traditional classification of innovative development factors of industry, all factors are considered in a certain order, established by many researchers. The classification of innovative factors of industrial development according to their priority is given. In this classification, the priority is determined by the importance and relevance of the tasks of innovative industry development, based on the conclusions drawn as a result of a review of the literature. Generalization of innovative development factors in the barrier classification allows us to distinguish three aggregated groups of factors: socio-political and managerial, socioeconomic, and financial.

In addition, our socio-economic analysis of factors of innovative development of industry also allowed us to identify the following their classification attributes: the hierarchical level of implementation of innovation, the nature of the demand for innovation, the nature of the impact on the market environment, the nature of influence, the time horizon of action, impact on the area of innovation localization, the economic nature of innovation, the nature of the significance of innovation, innovation effect, the nature of effective influence, the power of influence, type of competition. The applied value of these classifications lies in their specific spatiotemporal situational use in the development of planning and forecasting documentation and provisions of industrial policy. For example, when planning the introduction of innovations, the classification of factors is taken into account in the time horizon of action, which allows you to plan in advance the development of funds for them. The economic policy of the state should use the classification of factors according to the hierarchical level of innovation creation, etc.

\section{References:}

Alayev, E. B. (1983). Sotsial'no-ekonomicheskaya geografiya: ponyatiyno-terminologicheskiy slovar' [Socio-economic geography: conceptual-terminological dictionary]. Moscow: Thought. (in Russian)

Ansoff, I. (1979). Strategic Management. Palgrave Macmillan.

Bozhkova, V. V. (2011). Teoretyko-metodychni zasady formuvannya optymal'noyi struktury marketynhovykh komunikatsiy dlya prosuvannya promyslovykh innovatsiy [Theoretical and methodological principles of formation of optimal structure of marketing communications for promotion of industrial innovations]. Efektyvna ekonomika [Effective economy], vol. 1. Available at: http://nbuv.gov.ua/UJRN/efek 2011122 (in Ukrainian)

Horodyskyy, T. I. (2007). Innovatsiynyy potentsial: factory vplyvu [Innovative Potential: Impact Factors]. Naukovyy visnyk NLTU Ukrayiny [Scientific Bulletin of National Forestry University of Ukraine], vol. 17(2), pp. 276-284. (in Ukrainian)

Ihnatenko, O. Ya. (2008). Stymulyuvannya innovatsiynoho rozvytku promyslovykh pidpryyemstv [Stimulation of innovative development of industrial enterprises]. Website of Donetsk National Technical University. Available at: http://www.masters.donntu.edu.ua/2008/fem/ignatenko/library/st1.html (in Ukrainian)

Illyashenko, S. M. (2010). Innovatsiynyy menedzhment [Innovation Management] (Textbook). Sumy: University Book.

Keynes, J. M. (1936). The General Theory of Employment, Interest and Money. In: Keynes J. M. Collected Writings, vol. 7.

Kolodiychuk, A. V. (2017). Entrepreneurial risk theories as component of the theoretical foundations of informatization processes in the national economy. Ikonomicheski izsledovaniya [Economic Research], vol. 26(6), pp. 104-117. Available at: https://www.researchgate.net/publication/323412759_

Kuzmin, O. Ye., \& Kuzhda, T. (2009). Faktory innovatsiynoho rozvytku pidpryyemstv [Factors of innovative development of enterprises]. Ukrainian Expert Net: Website. Available at: http://www.experts.in.ua/baza/analytic/ index.php?ELEMENT_ID=11391 (in Ukrainian)

Panteleychuk, D. Yu. (2009). Innovatsiyna diyal'nist' mashynobudivnykh pidpryyemstv [Innovative activity of machine-building enterprises]. Available at: http://www.vstu.vinnica.ua (in Ukrainian) 
Solyanyk, L. H., \& Hrachova, Yu. M. (2008). Analiz mashynobudivnoho kompleksu Ukrayiny: osnovni tendentsiyi investytsiynoyi ta innovatsiynoyi diyal'nosti $\mathrm{v}$ haluzi [Analysis of the machine-building complex of Ukraine: main tendencies of investment and innovation activity in the industry]. Available at: http://www.rusnauka.com/31_PRNT_2008/Economics/36566.doc.htm (in Ukrainian)

Somenkova, N. S. (2008). Formirovaniye strategii innovatsionnogo razvitiya promyshlennogo predpriyatiya [Formation of the strategy of innovative development of an industrial enterprise]. Economics and Finance: Bulletin of the Nizhniy Novgorod University n.a. N.I. Lobachevsky, vol. 1, pp. 160-162. (in Russian)

Shevchuk, L. T. (2011). Rehional'na ekonomika [Regional economics] (Teaching manual). Kyiv: Znannya. (in Ukrainian)

Shults, S. L. (2010). Ekonomichnyy prostir Ukrayiny: formuvannya, strukturuvannya ta upravlinnya [Economic space of Ukraine: formation, structuring and management]. Lviv: Dolishniy Institute of Regional Research of NAS of Ukraine. (in Ukrainian) 